\title{
Impact of Soil Moisture on Crop Yields over Brazilian Semiarid
}

\author{
Luciana Rossato ${ }^{1 *}$, Regina C. dos Santos Alvalá2, José A. Marengo ${ }^{2}$, Marcelo Zeri $^{2}$, \\ Ana P. M. do Amaral Cunha ${ }^{2}$, Luciana B. M. Pires ${ }^{3}$ and Humberto A. Barbosa ${ }^{4}$
}

${ }^{1}$ Barcelona Expert Center, Polytechnic University of Catalonia, Barcelona, Spain, ${ }^{2}$ National Center for Monitoring and Early Warning of Natural Disasters, São José dos Campos, Brazil, ${ }^{3}$ Science for the World Research Institute, Atlanta, GA, United States, ${ }^{4}$ Instituto de Ciências Atmosféricas, Universidade Federal de Alagoas, Maceió, Brazil

OPEN ACCESS

Edited by:

Christos H. Halios,

University of Reading, United Kingdom

Reviewed by:

Gunter Spöck,

Alpen-Adria-Universität Klagenfurt, Austria

ljaz Hussain,

Quaid-i-Azam University, Pakistan

*Correspondence:

Luciana Rossato

luciana.rossato@tsc.upc.edu

Specialty section:

This article was submitted to

Environmental Informatics,

a section of the journal

Frontiers in Environmental Science

Received: 31 May 2017

Accepted: 16 October 2017

Published: 07 November 2017

Citation:

Rossato L, Alvalá RCdS, Marengo JA,

Zeri M, Cunha APMdA, Pires LBM and Barbosa HA (2017) Impact of Soil Moisture on Crop Yields over Brazilian

Semiarid. Front. Environ. Sci. 5:73. doi: 10.3389/fenvs.2017.00073
The objective of this work was to investigate the relationship between soil water content and rainfall with rice, beans, cassava and corn yields in the semiarid region of Northeast Brazil. Precipitation and modeled soil water content were compared to yields recorded at the county levels in this region. The results were also integrated over the area of the nine States that lie within the officially recognized region of semiarid climate in Brazil. The influence of water balance components was quantified by calculating their correlation coefficient with yields of the different crop species over the municipalities of the region. It was found that rainfall had higher correlation to crop yields over most of the region, while soil water content had lower values of correlation. This result is consistent with the fact that average root depth is $40 \mathrm{~cm}$, lower than the layer of soil used in the model used to estimate soil water content $(100 \mathrm{~cm})$. Plants respond better to the precipitation in the top layers of soil, while the water storage in the deep layer of soil might be important only in other temporal and spatial scales of the hydrological cycle.

Keywords: soil moisture, rainfall, crop yield, Brazilian semiarid region

\section{INTRODUCTION}

Semiarid regions represent $30 \%$ of the global terrestrial area and are located in the Americas, Oceania, Asia and Africa. In the South American continent, these regions are in Venezuela, Colombia, Argentina, Chile, Ecuador and Brazil. There are currently 1,136 counties included in the semiárid region of Brazil, occupying an area of $969,589.4 \mathrm{~km}^{2}$, which are distributed in eight States of the Northeast region of Brazil (NEB), excluding the State of Maranhão, and including part of the region southeast (part of the State of Minas Gerais). A population of 23.15 million people lives in these regions (Scanlon et al., 2006).

The semiarid region is characterized by natural vegetation called caatinga, high temperatures and unstable rainfall, both in the temporal and space dimension. The main feature of the semiarid region is frequent drought caused by the prolonged absence of rain (Barbosa et al., 2015; Barbosa and Lakshmi Kumar, 2016; Marengo et al., 2016).

The social implications related to droughts were pointed out in Paredes et al. (2015), and may be of four types: (1) meteorological: when precipitation is far below the normal; (2) hydrological: when the river flow can not attend to demands of a given system of water management; (3) agricultural: when there is not enough moisture in the soil for development of a crop at any stage of growth; (4) socioeconomic: when there is reduction of the availability of water and this causes damage and impacts to the population. 
Agricultural drought is due to water deficiency in soil and consequent water stress to plants, causing the reduction in the biomass production. Thus, the assessment of soil moisture conditions and the estimation of effects of drought/water excess are relevant, and are important information associated with decline in agricultural yield. Thus, the assessment of soil moisture and rainfall in semiarid regions is crucial to understanding the variability in these areas and to support actions to mitigate the effects of water scarcity. Various studies have been conducted evaluating different semiarid regions of the world (Small and Kurc, 2002; Aina et al., 2007; Fischer et al., 2009; Asare et al., 2011; Mupangwa et al., 2011; Pathak et al., 2011; Zhang et al., 2011; Badel et al., 2013; He et al., 2014; Barbosa et al., 2015; Paredes et al., 2015; Barbosa and Lakshmi Kumar, 2016).

The agricultural production in the semiarid region of Brazil is predominantly (about 90\%) made up of family farms, most consisting of dryland systems in plantations, characterized by low productivity rates (IBGE, 2006). Inadequate availability of water in the soil is the main obstacle to agricultural production, making it the primary limiting factor to achievement of high agricultural productivity over the years. In addition, extreme variability in climatic conditions also influences agricultural productivity, i.e., in some years, the water supply to plants is sufficient to achieve high crop yields; while in other years, inadequacy can lead to total loss of crops (Antonino et al., 2000).

In the northeastern hinterland, the lack of access to water resources and recurring drought have affected agricultural activities for centuries, causing, among other problems, poor nutrition and migration (Obermaier, 2011; Marengo et al., 2016). The recent great drought that started in 2012 and that extended until 2017 produced impacts in about 1.300 counties, affecting more than 10 million people. In the economy, generated a loss of approximately R $\$ 6.8$ billion in crop loss (IBGE, 2013; Mi et al., 2014; Marengo et al., 2016).

Future climate projections indicate risk of severe droughts, rainfall reductions up to $40 \%$ and increase of consecutive dry days in semiarid regions (Marengo et al., 2016). The impacts of these changes may directly affect about 7 million people linked to family farming in the NEB, who are often found in extreme poverty (IBGE, 2006; Lindoso et al., 2011).

Whereas agriculture is vulnerable to the impacts of climate variability, many studies have been conducted to assess the impact of climate change on crop yield on various crops. Recently, Trnka et al. (2015) showed the increasing severity of drought due to climate change, assessing the overall soil moisture conditions for the period 1961-2012 in Central Europe. This region has been characterized by a series of drought events with substantial impacts, especially on agricultural production. According to the general farming, and vegetation systems, this region has been adapted to the uniform distribution of rainfall, the region is susceptible to the droughts even in the short term. The authors also pointed out that the drought events are from multi-decadal climate variability or from atmospheric circulation patterns. In Brazil, Rao et al. (1997) analyzed the interannual variations of rainfall associated with corn yield in the NEB. The results showed that the Inter-Tropical Convergence Zone occurring in southern Brazil is probably responsible for most increases in rainfall in the NEB. In 6 of the 9 States of the region, the precipitation correlated significantly with corn harvest, while in 7 of the 9 States, the Southern Oscillation Index (SOI) showed a strong positive correlation with annual corn yields, suggesting that the rate of SOI can be used to predict annual corn yields in the NEB.

However, there are few studies focusing on assessment of the impact of soil moisture on agricultural productivity (Kang et al., 2009; Carrão et al., 2016), considering different crops on a regional scale in the Brazilian semiarid region. Previous work on water balance primarily considered soil cultivated with corn and beans (Antonino et al., 2000), not including, for example, the crops of rice and cassava, which are also basic food products of NEB (Metri et al., 2003).

Therefore, this study aimed to evaluate the impact of the soil moisture, estimated by a water balance model, for agricultural subsistence production (rice, beans, cassava, and corn) from the Brazilian semiarid area, using crop average yield information and meteorological (rainfall and water storage in the soil) information during the period from 2000 to 2012.

\section{MATERIALS AND METHODS}

\section{Study Area and Climatology}

As previously pointed out, the semiarid region of Brazil (SAB) extends from the northern of the Piaui State to the north of Minas Gerais, as illustrated in Figure 1. Due to their different physical characteristics, the region is divided into four sub-regions: midnorth, wilderness (sertão), wild (agreste) and forest zone (zona da mata), with the Human Development Index (HDI) varied over their geographical areas (mean of 0.6589 ). The HDI is a summary measure for assessing progress in three basic dimensions of human development: a long and healthy life, access to knowledge and a decent standard of living (UNDP, 2013).

One of the Brazilian semi-arid landscape features is the vegetation of caatinga, which is a biome with great biodiversity. The Caatinga is now one of the most threatened biomes by inappropriate use of its resources. The inappropriate land use combined with climatic variations and soil characteristics may lead a desertification process and the gradual loss of biological soil fertility (INSA, 2014).

According to Ab'Saber (1977), the partial desertification processes occur in a spreading circular fashion, causing irreversible degradation of the landscape. The process results in degradation of the environment to a desert- type landscape condition, producing loss of soil, scarcity of water resources, reduction or loss of biological productivity, unproductive agriculture and abandonment of land due to reduction of the land's ability to sustain human activities, for example, crop production, pasture, and fuel (IPCC, 2014-WG2), resulting in reduced quality of life of affected populations. The regions located between the wet and dry areas transition bands suffer more degradation than the caatingas areas that are already adapted to semiarid conditions.

The Brazilian semiarid region is also characterized by having large spatial and temporal variability of rainfall and frequent droughts (Moura and Shukla, 1981; Tenório, 1989; Hastenrath, 


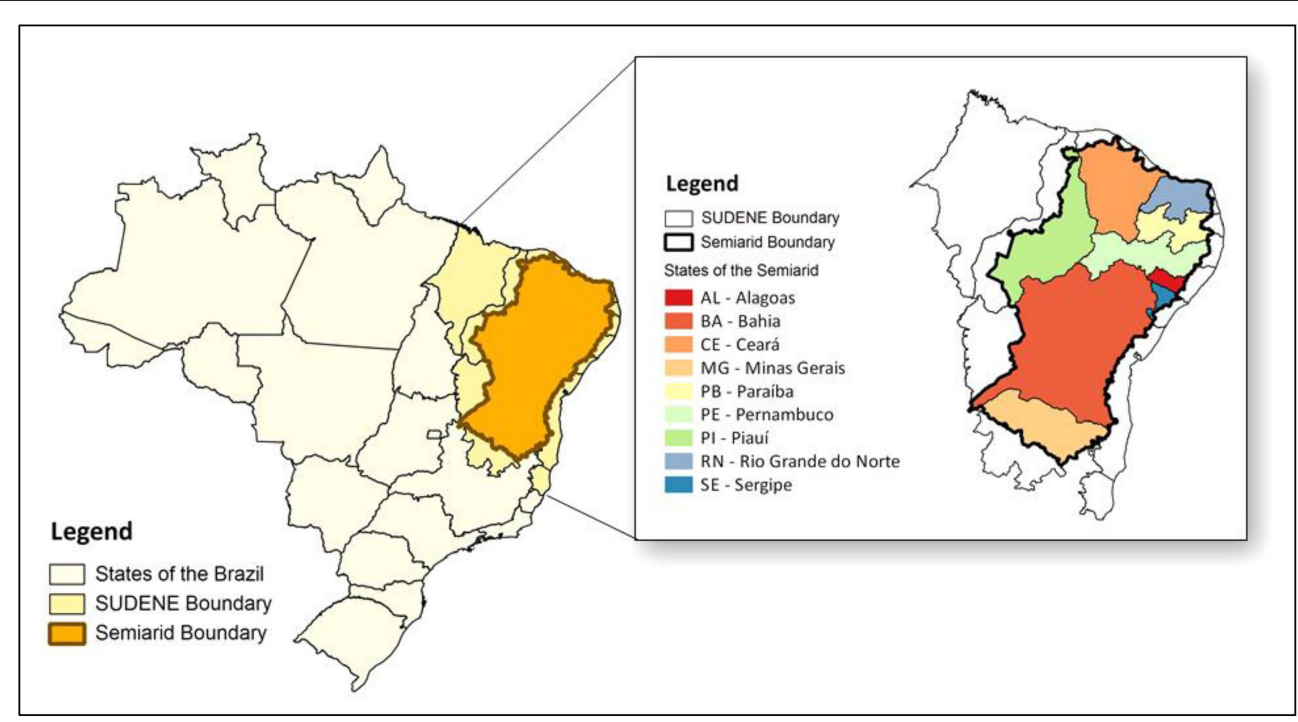

FIGURE 1 | Geographical location of the Brazilian Semiarid region in Brazil.

2006). Rainfall within the semiarid NEB is concentrated from December to April in the northern sector and from November to March in the south of the region (Rao et al., 1993; Molion and Bernardo, 2002). According to Moscati and Gan (2007), in 20 years (1977-1997) few extreme rainfall events (rainfall above $10 \mathrm{~mm} \mathrm{day}^{-1}$ for at least 4 consecutive days) occurred in this region, 15 cases in the northern sector of the region and 31 cases in the southern sector. The occurrence of heavy rain inside the semiarid region is due to the action of synoptic systems, such as: the frontal system, the cyclone vortice of high levels (UTCV) and the South Atlantic Convergence Zone (SACZ). Other atmospheric systems acting in the NEB region are Easterly Waves Disturbances, Intertropical Convergence Zone, and Frontal Systems. These phenomena directly and indirectly influence rainfall over the NEB region. Also, the positive and negative precipitation anomalies over the south of the Northeast are associated with positive and negative phases of the ENSO phenomena, respectively (Hastenrath, 2012; Marengo et al., 2013, 2016).

Molion and Bernardo (2002) presented a review of the dynamics of the rainfall in NEB, noting that the North Northeast (covering the Ceara State and parts of the Rio Grande do Norte, Piaui, Maranhão and west of Paraiba and Pernambuco States) is characterized with maximum rainfall in March. The rainfall varies from $400 \mathrm{~mm} /$ year (interior) to more than 2,000 mm/year (coastal), while the four wettest months are between February and May (FMAM). In the southern part, which covers the State of Bahia, the north of Minas Gerais, the northwest of Espirito Santo, the southern parts of the Maranhão (MA) and Piauí (PI) and the extreme southwest of Pernambuco (PE), the rainfall varies from $600 \mathrm{~mm} /$ year (interior) to more than $3,000 \mathrm{~mm} /$ year (coastal), with the wettest period between the months of November to February. The coastal strip, stretching from Rio Grande do Norte (RN) to south of Bahia (BA), also known as the Zona da Mata, has annual rainfall totals ranging from 600 to $3,000 \mathrm{~mm}$. Its wettest period runs from April to July, with peak rainfall in May. According to Silva et al. (2012), the variability of rainfall in the Northeast of Brazil has a strong influence on the agriculture.

The severe droughts caused by climatic variations impair the growth of crops and consequently cause serious social problems, since much of the population inhabiting the region live in extreme poverty (Marengo et al., 2009, 2016). Thus, the livelihood and food security of millions of small farmers are exposed to the risk of drought, since the semi-arid population is conditioned to survive mainly on economic activities related to agriculture and livestock in a highly vulnerable environment. The population in general seeks the best possible utilization of the adverse natural conditions, although supported in a weak basic technique using, in most cases, traditional technologies (SUDENE, 2014).

\section{Agricultural Production Data}

Agricultural yield is highly dependent on interactions between phenomenological stages and interannual variations of weather and climate. Losses of agricultural crops are directly related to the occurrence of adverse weather (rain, drought, frost, hail, etc.). When the weather requirements for crop production are not satisfied, the crop failure will be proportional to the duration and severity of adverse weather conditions.

Information provided by the Brazilian Institute of Geography and Statistics (IBGE) were used for the measurement of farm performance of the four different types of crops mentioned (rice, beans, cassava and corn) during the dry season and during excessive rains in the Brazilian semiarid region. The average performance data (productivity and cultivated area), obtained from the IBGE (available on the site http://www.sidra.ibge.gov. br/bda/agric/) during the period of 2000 to 2012 were used for evaluation of the impact of soil moisture in the agricultural production of 1,135 counties in the Brazilian semiarid region. 


\section{Rainfall Data and Water Storage in the Soil}

Rainfall data and water storage in the soil extracted from the MUSA Project (http://musa.cptec.inpe.br/) for the period of 2000-2012 were considered in the evaluation of the possible impacts of meteorological phenomena on agriculture. Estimates of the soil water were obtained by integrating soil and weather information. The soil information is from soil surveys conducted by Embrapa (Brazilian Agricultural Research Corporation) and in the scope of RadamBrasil Project, which include the depth of horizons, soil type, vegetation type, etc. It is noteworthy that for each horizon, physical (texture, structure, etc.) and chemical (organic matter, macro and micro nutrients, carbon, etc.) analyses were performed, as well as for obtaining the water storage in soil, it was used pedo-transfer functions-PTF (Tomasella et al., 2000). The pedo-transfer function (PTF) utilized in this study was adapted from the work of Rossato et al. (2004), which was calculated from data of the basic soil properties (texture, organic carbon content, equivalent moisture, and bulk density), using the van Genuchten retention equation (van Genuchten, 1980). Multiple linear regression techniques were used, using a second-order polynomial with linear coefficients.

Weather information utilized for the water balance in the soil are derived from the data platform network available on the National Institute for Space Research (INPE) and by the synoptic network data from the National Institute of Meteorology (INMET), which allow the estimation of evapotranspiration using the Penman-Monteith model, according to the methodology presented by Allen et al. (1998). The data necessary for the application of this model are: global incident radiation, temperature and relative humidity, wind speed and pressure. Considering that the synoptic network from INMET has no radiation sensors available, the estimates of daily radiation are derived from the information provided by GOES sensors and by the model proposed by Ceballos and Moura (1997).

The daily precipitation figures were obtained considering data observed in situ by rain gauges, from different State and national centers of meteorology and integrated by INPE. Precipitation estimates from the product 3B42 from the Tropical Rainfall Measuring Mission satellite (TRMM), available at http://daac. gsfc.nasa.gov/precipitation/TRMM_README/TRMM_3B42_ readme.shtml, were utilized. The observations were grouped according to the cells defined by the resolution of the TRMM data $\left(0.25^{\circ} \times 0.25^{\circ}\right)$. The precipitation and soil moisture database were interpolated using Kringing method.

\section{RESULTS AND DISCUSSIONS}

\section{Spatial Distribution of Agricultural Performance in the Sab States}

The impact of soil water conditions on yields of rice, beans, cassava and corn was evaluated by farm performance information available for 1,136 counties in the Brazilian semiarid region, during the period of 2000-2012. Figure 2 illustrates the time series of the average yield of rice crops, beans, cassava and corn for each State of the Brazilian semiarid.
According to the agricultural data from the IBGE, in the period of 12 years, the State of Sergipe had the highest rice yield $(5,000 \mathrm{~kg} / \mathrm{ha})$, followed by the State of Pernambuco, with approximately $2,700 \mathrm{~kg} / \mathrm{ha}$. In contrast, the State of Piauí had the lowest yields of rice and bean crops, with approximate values of 850 and $220 \mathrm{~kg} / \mathrm{ha}$, respectively. For the bean crop, the State of Minas Gerais stands out as the largest producer (average yield of $800 \mathrm{~kg} / \mathrm{ha}$ in 2008), while the State of Piauí presented the lowest average yield (124 kg/ha in 2012). The highest yield of cassava was registered in the State of Piauí, in the year $2000(14,000 \mathrm{~kg} / \mathrm{ha})$, while the lowest was in 2012 (average yield of 4,090 kg/ha). As for the corn crop, the State of Sergipe had the highest yield, reaching higher than $2,500 \mathrm{~kg} / \mathrm{ha}$.

The high productivity of agricultural crops in the State of Sergipe, according to CODEVASF (Development Company of the São Francisco and Parnaíba Valeys), is explained by the use of irrigation adopted by producers of the Lower São Francisco of Sergipe region and the irrigated sub-regions of Propriá, Cotinguiba/Pindoba and Betume, culminating in increased production of rice, beans, cassava and corn. It is emphasized that the partnership between CODEVASF, and the government of Sergipe, through the Secretariat of the State for Agriculture (SEAGRI) involved the acquisition of 210 tons of rice seed and passed on to the producers of the three irrigated regions. The Bank of the State of Sergipe-BANESE-also decisively supported the implementation of the crop by funding various irrigation projects for agricultural development (http://www. codevasf.gov.br). Recently, the Most Irrigation Program, run by the Ministry of National Integration, invested $\mathrm{R} \$ 102$ million to be invested in these three irrigation schemes, focusing on rehabilitation of the drainage system (http://www.integracao.gov. br/web/guest/noticias).

In order to verify the percentage of the yield of each crop in the different States of the SAB in the last 12 years, we calculated the average yield for the period from 2000 to 2012, for the rice, bean, cassava and corn crops, as illustrated in Table $\mathbf{1}$.

Note that, from the values presented in 2012, the largest loss of rice crops occurred in the States of CE, PI and PB. For harvest of beans, it was observed that the States of CE, PB, AL, and PI had a loss of 52, 50, 46, and 43\%, respectively. The States of PI, CE and BA had the highest average losses of cassava yield. A drop in the corn crop yield occurred in the States of Ceará (CE), Alagoas $(\mathrm{AL})$ and Paraíba (PB), with values between 60 and $46 \%$ below the average performance from 2000 to 2012 .

\section{Impacts of Water Availability in Agricultural Production}

Considering that agricultural productivity is directly related to climatic conditions, especially with precipitation and soil water availability, the daily data from the MUSA Project were evaluated in relation to the average yield of rice crops, beans, cassava and corn in the semiarid region.

Figures 3, 4 illustrate the spatial and temporal distribution of rainfall ( $\mathrm{mm} /$ day) and water storage in the soil ( $\mathrm{mm})$ annual averages for the Brazilian semiarid region. For precipitation, the lowest values are represented by shades of light blue, while the 


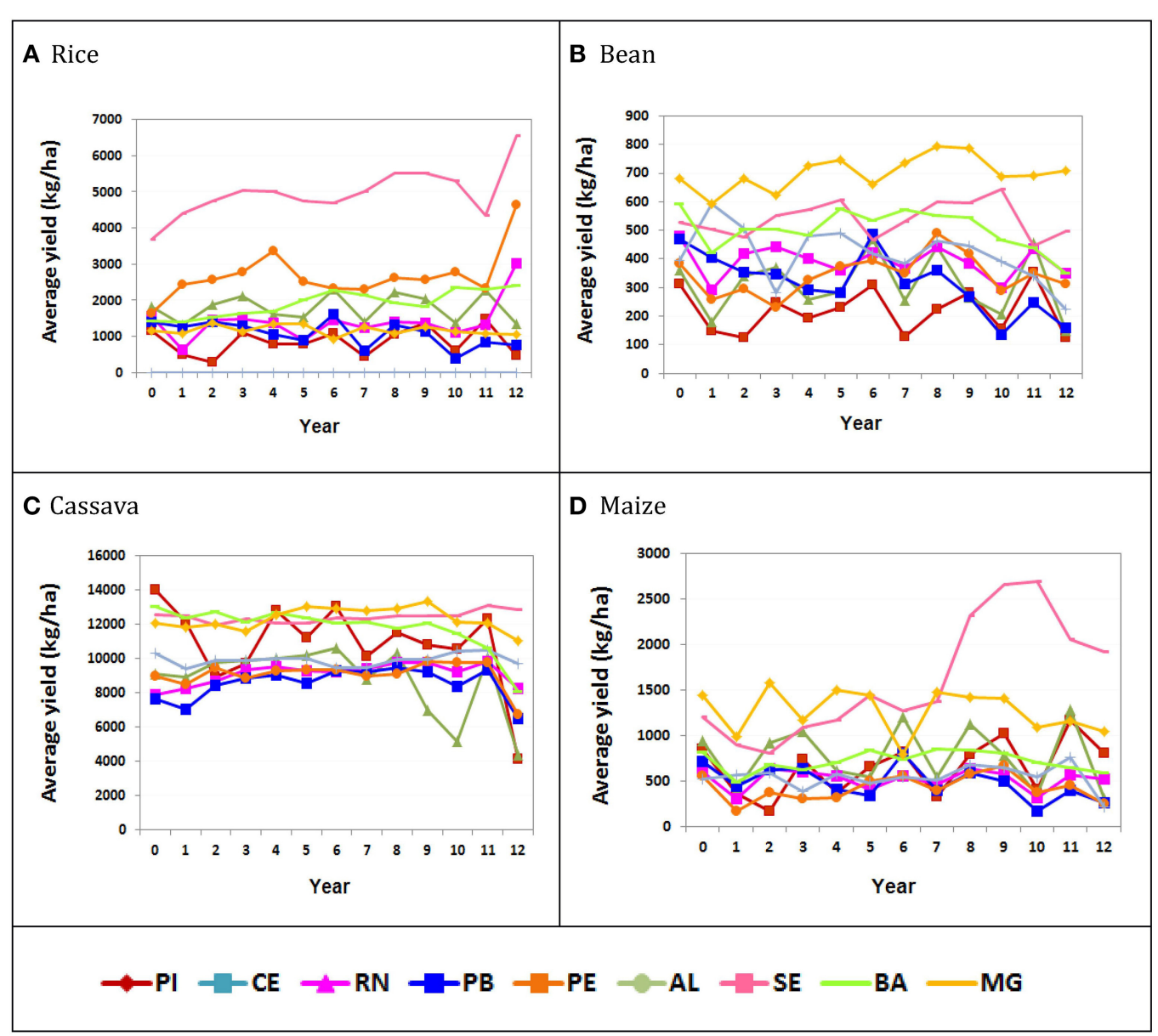

FIGURE 2 | Average yield (Kg/ha) of the seasonal crop production during the period of 2000-2012 for each state in the Brazilian semiarid crop: (A) rice; (B) beans; (C) cassava; (D) maize.

stronger shades of blue are representative of higher rates. In Figure 4, higher water contents in the soil are represented by the color green, while lower values are in color shades of brown.

The results show that for the years 2003 and especially the year 2012, the study area showed lower precipitation values in relation to those observed in other years. According to the Marengo et al. (2013), the El Niño-Southern Oscillation (ENSO) was responsible for the drought above the historical average in the Northeast of Brazil during December 2002 to April 2003. This explains, in large part, the problems that occurred with the first bean harvest 2002/2003 in the country, which had delayed planting in several regions and caused harvest problems, mainly in the south of the country, with the consequent increase in price levels in the second half of November, by which time a drop in prices usually occurs, with an increase in the quantity supplied. The drought of 2012 was considered the worst in 30 years in the NEB, causing an increase in food prices (Leivas et al., 2012). As an impact of the intensification of drought, farm performance was reduced in 2012 in the region, mainly for the bean crops, corn, and cassava. According to Guimarães et al. (2013), in the years of 2012/2013 only planting and harvesting cassava was possible in the Minas Gerais semiarid region. According to Marengo et al. $(2013,2016)$, drought conditions in northeastern Brazil started in December of 2011 in the northern sector of the region, and in the following months extended to the entire region, with maximum intensity reached in the usually rainy season from February to May of 2012. The soil moisture content variability is dependent on precipitation (Rossato et al., 2011); although they are not directly correlated. The results in Figure $\mathbf{4}$ show a decrease in the water storage in soil for the Brazilian semiarid region, both in 2003 and in 2012, the last year showing the lowest levels of water in soil values.

In order to verify the degree of correlation between precipitation and water storage in the soil for the whole of the Brazilian semiarid region, the correlation coefficient was calculated. Figure 5 illustrates the spatial distribution of the average values during the period 2000-2012, from the precipitation and available water content products, as well as the correlation coefficient obtained between these two variables. The results show that both variables are correlated with values $>0.5$ for almost the entire region. This result may be associated with periods of drought in the NEB caused by high 
TABLE 1 | Average percentage of agricultural income for rice crops, beans, cassava and maize during the period of 2000-2012, for the states of the Brazilian semiarid region.

\begin{tabular}{|c|c|c|c|c|c|c|c|c|c|c|c|c|c|c|c|c|c|c|c|}
\hline \multirow{3}{*}{ Year } & \multicolumn{19}{|c|}{ Average percentage of agricultural income for the states of the Brazilian Semiarid region } \\
\hline & \multicolumn{9}{|c|}{ Rice } & \multirow[t]{2}{*}{ Year } & \multicolumn{9}{|c|}{ Bean } \\
\hline & PI & CE & RN & PB & PE & AL & SE & BA & MG & & PI & CE & RN & PB & PE & AL & SE & BA & MG \\
\hline 2000 & 35 & 2 & 11 & 31 & -39 & - & -26 & -26 & -1 & 2000 & 43 & 16 & 22 & 48 & 11 & -5 & -2 & 17 & -3 \\
\hline 2001 & -42 & -26 & -55 & 18 & -9 & - & -11 & -27 & -9 & 2001 & -31 & -43 & -25 & 28 & -25 & 42 & -7 & -16 & -16 \\
\hline 2002 & -65 & 5 & 3 & 31 & -4 & - & -4 & -20 & 17 & 2002 & -42 & 10 & 7 & 11 & -14 & 22 & -12 & 0 & -3 \\
\hline 2003 & 29 & 19 & 5 & 20 & 3 & - & 2 & -15 & -3 & 2003 & 14 & 20 & 13 & 10 & -33 & -33 & 2 & 0 & -11 \\
\hline 2004 & -8 & -10 & -2 & -1 & 26 & - & 1 & -11 & 14 & 2004 & -12 & -17 & 3 & -8 & -6 & 16 & 6 & -4 & 4 \\
\hline 2005 & -8 & -15 & -36 & -16 & -6 & - & -5 & 5 & 16 & 2005 & 6 & -9 & -8 & -11 & 9 & 18 & 12 & 15 & 7 \\
\hline 2006 & 28 & 29 & 4 & 49 & -13 & - & -5 & 18 & -22 & 2006 & 42 & 51 & 8 & 54 & 15 & 0 & -13 & 6 & -6 \\
\hline 2007 & -49 & -22 & -12 & -45 & -14 & - & 1 & 11 & 8 & 2007 & -41 & -18 & -6 & -1 & 2 & -7 & -1 & 13 & 5 \\
\hline 2008 & 23 & 24 & -1 & 23 & -2 & - & 11 & 1 & -7 & 2008 & 2 & 43 & 13 & 14 & 43 & 11 & 11 & 10 & 13 \\
\hline 2009 & 60 & 15 & -3 & 7 & -4 & - & 11 & -5 & 8 & 2009 & 29 & -15 & -2 & -15 & 21 & 7 & 11 & 8 & 12 \\
\hline 2010 & -29 & -24 & -22 & -64 & 3 & - & 7 & 23 & -3 & 2010 & -28 & -33 & -24 & -58 & -16 & -6 & 19 & -7 & -2 \\
\hline 2011 & 73 & 28 & -7 & -22 & -14 & - & -12 & 20 & -7 & 2011 & 61 & 47 & 11 & -22 & 2 & -19 & -18 & -13 & -2 \\
\hline 2012 & -46 & -25 & 114 & -30 & 73 & - & 32 & 26 & -11 & 2012 & -43 & -52 & -11 & -50 & -9 & -46 & -8 & -30 & 1 \\
\hline Year & \multicolumn{9}{|c|}{ Cassava } & Year & \multicolumn{9}{|c|}{ Maize } \\
\hline 2000 & 29 & 3 & -14 & -11 & -1 & 4 & 1 & 10 & -2 & 2000 & 31 & 21 & 15 & 49 & 31 & -3 & -25 & 14 & 14 \\
\hline 2001 & 12 & 2 & -10 & -18 & -6 & -5 & 0 & 5 & -4 & 2001 & -45 & -48 & -41 & -8 & -60 & 4 & -44 & -32 & -22 \\
\hline 2002 & -18 & 11 & -5 & -1 & 5 & -1 & -4 & 8 & -3 & 2002 & -74 & 18 & 22 & 30 & -12 & 9 & -50 & -6 & 24 \\
\hline 2003 & -11 & 13 & 2 & 4 & -2 & 0 & -1 & 3 & -6 & 2003 & 14 & 35 & 15 & 32 & -29 & -28 & -33 & -13 & -8 \\
\hline 2004 & 18 & 14 & 5 & 6 & 2 & 1 & -3 & 8 & 2 & 2004 & -43 & -21 & 8 & -15 & -25 & 8 & -27 & -2 & 18 \\
\hline 2005 & 3 & 16 & 2 & 0 & 3 & 1 & -3 & 5 & 6 & 2005 & 1 & -30 & -21 & -31 & 19 & -12 & -10 & 17 & 14 \\
\hline 2006 & 20 & 21 & 1 & 9 & 3 & -5 & -1 & 2 & 5 & 2006 & 25 & 56 & 7 & 66 & 32 & 0 & -21 & 3 & -37 \\
\hline 2007 & -7 & 0 & 3 & 8 & -1 & -4 & -1 & 3 & 4 & 2007 & -50 & -30 & -11 & -19 & -7 & -5 & -14 & 18 & 17 \\
\hline 2008 & 6 & 18 & 7 & 11 & 1 & 0 & 1 & -1 & 5 & 2008 & 21 & 46 & 23 & 21 & 36 & 27 & 44 & 18 & 12 \\
\hline 2009 & -1 & -20 & 7 & 8 & 9 & 0 & 1 & 2 & 8 & 2009 & 56 & 1 & 11 & 2 & 60 & 19 & 65 & 13 & 11 \\
\hline 2010 & -3 & -42 & 2 & -2 & 8 & 5 & 1 & -3 & -1 & 2010 & -38 & -55 & -38 & -64 & -11 & 0 & 68 & -2 & -14 \\
\hline 2011 & 13 & 15 & 8 & 10 & 8 & 6 & 5 & -10 & -2 & 2011 & 80 & 66 & 9 & -18 & 8 & 42 & 28 & -10 & -9 \\
\hline 2012 & -62 & -50 & -9 & -24 & -26 & -2 & 3 & -32 & -10 & 2012 & 24 & -60 & 1 & -46 & -42 & -60 & 20 & -17 & -18 \\
\hline
\end{tabular}

seasonal and interannual variability during the period 20002010; however, the most extreme events coincided with the occurrence of the ENSO episode, as pointed out by Paredes et al. (2015).

To assess the impact on agricultural output in detail, Figure 6 shows the average annual yield $(\mathrm{kg} / \mathrm{ha})$ for 4 different crops in the semiarid region of Brazil, according to the rainfall $(\mathrm{mm} / \mathrm{month})$ and water storage in the soil (mm), during the 2000-2012 period. It was noted that the largest decreases in precipitation and water storage in the soil occurred in 2012, mainly affecting the productivity of cassava, which had maintained a constant average value of productivity in the previous years. Santos et al. (2012) noted that the drought of 2012 in the Brazilian semiarid region affected agriculture, with significant losses in crops. The total cassava production in 2012 was lower by $71.51 \%$ as compared to the harvest in 2011. The results (Figure 6) show that the average yield decreased dramatically in some States during the drought year and increased during the neutral year, compared to the average. For the rice crop, there was an exception in the SE and PE States, which showed a drop of about $1,000 \mathrm{~kg} / \mathrm{ha}$ in the average performance during the year of 2000 compared to the average from 2000 to 2012; while in 2012 the average yield decreased in the States of BA, PE, SE and RN. In other States, the standards in neutral and drought years remained as expected. For the bean crop, the States in which higher average yield was obtained in 2000 were $\mathrm{BA}, \mathrm{PB}$, and $\mathrm{RN}$, while the $\mathrm{AL}, \mathrm{CE}, \mathrm{PB}$, and PI States showed the largest drop in performance in 2012. Regarding the average yield of the cassava crop, it was observed that in 2000 , the State of PI showed an increase of 2,000 kg/ha compared to the average. During 2012, the most affected States were BA, CE and IP. Finally, for the corn crop, the States of MG and PB showed yield values higher than average. In 2012, the AL, 


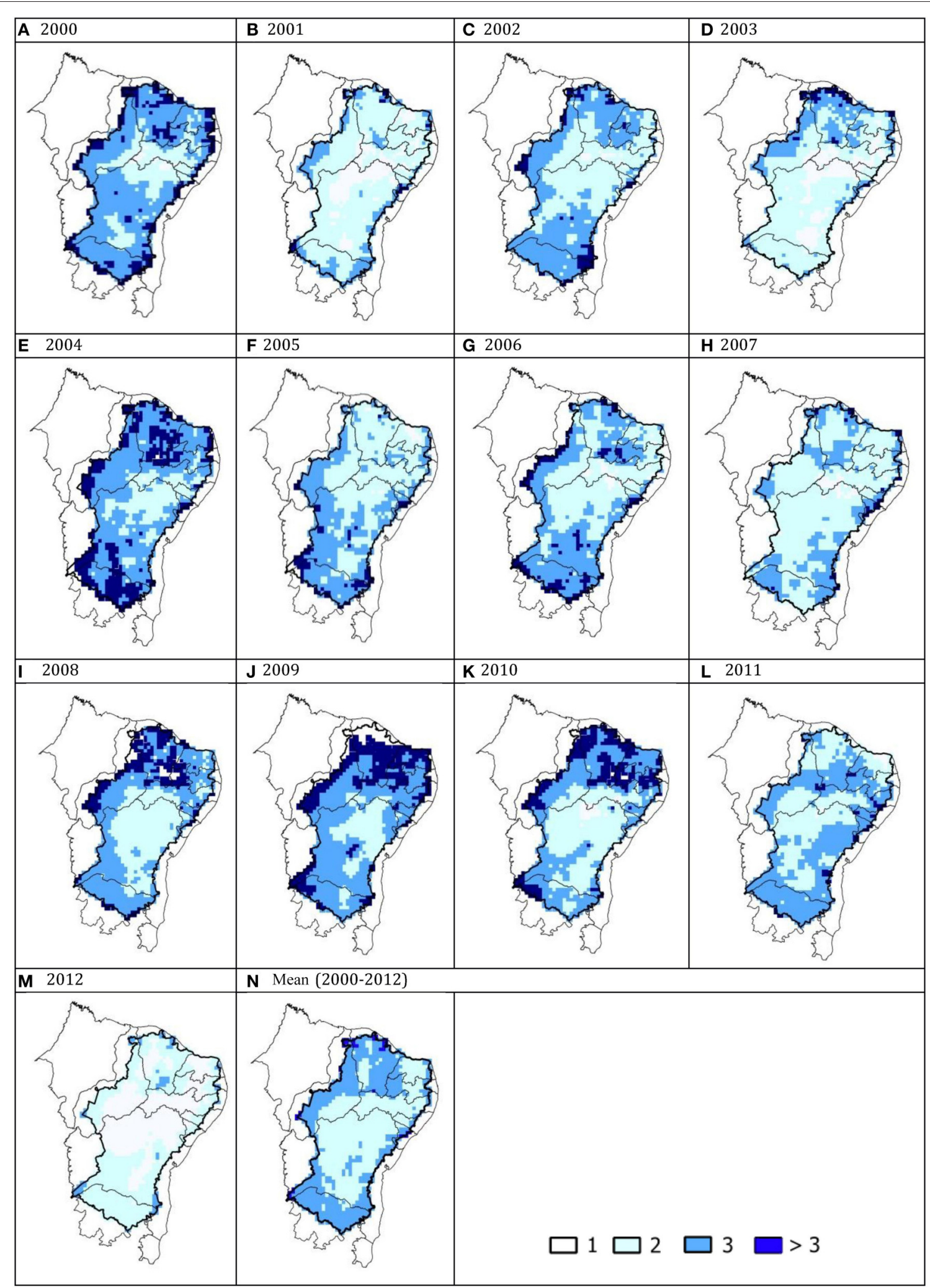

FIGURE 3 | Average annual rainfall (mm/day) for the region of semiarid region of Brazil during the period from 2000 to 2012. 


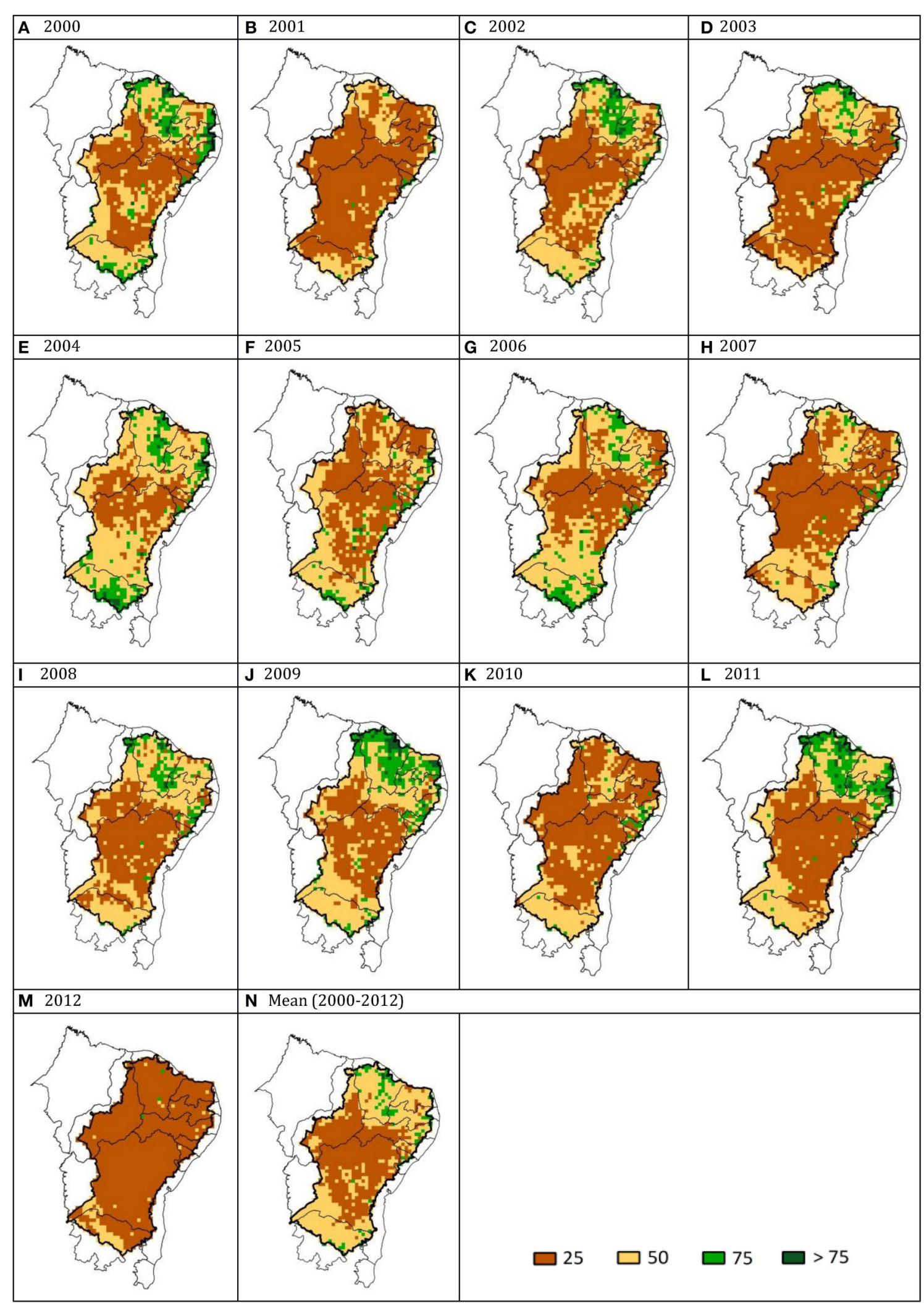

FIGURE 4 | Available water content (mm), annual average for the region of Semiarid of Brazil during the period from 2000 to 2012. 


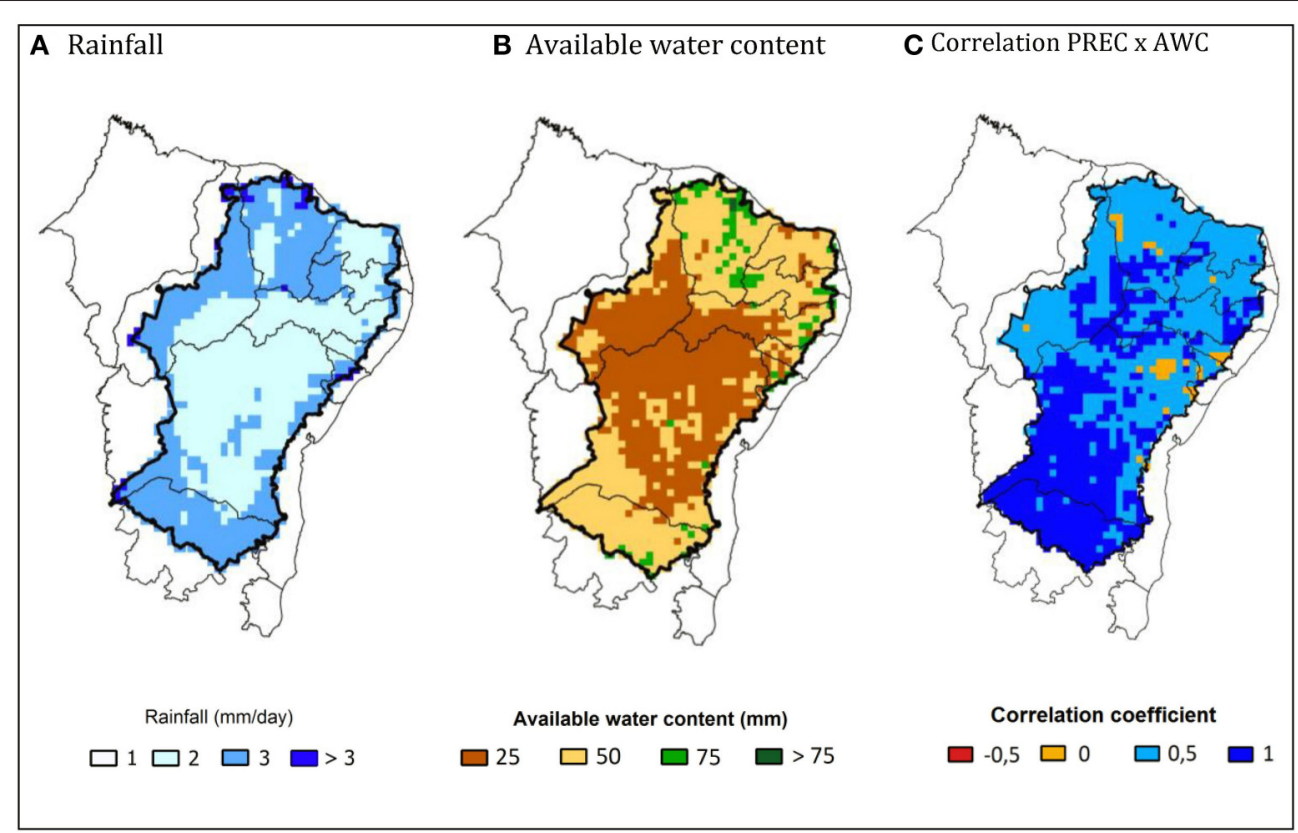

FIGURE 5 | Spatial-temporal distribution of rainfall-PREC ( $\mathrm{mm} /$ day) and available water content-AWC $(\mathrm{mm})$ annual average over the period of 2000-2012, and the correlation between the precipitation and storage for the Semi-Arid region of Brazil.

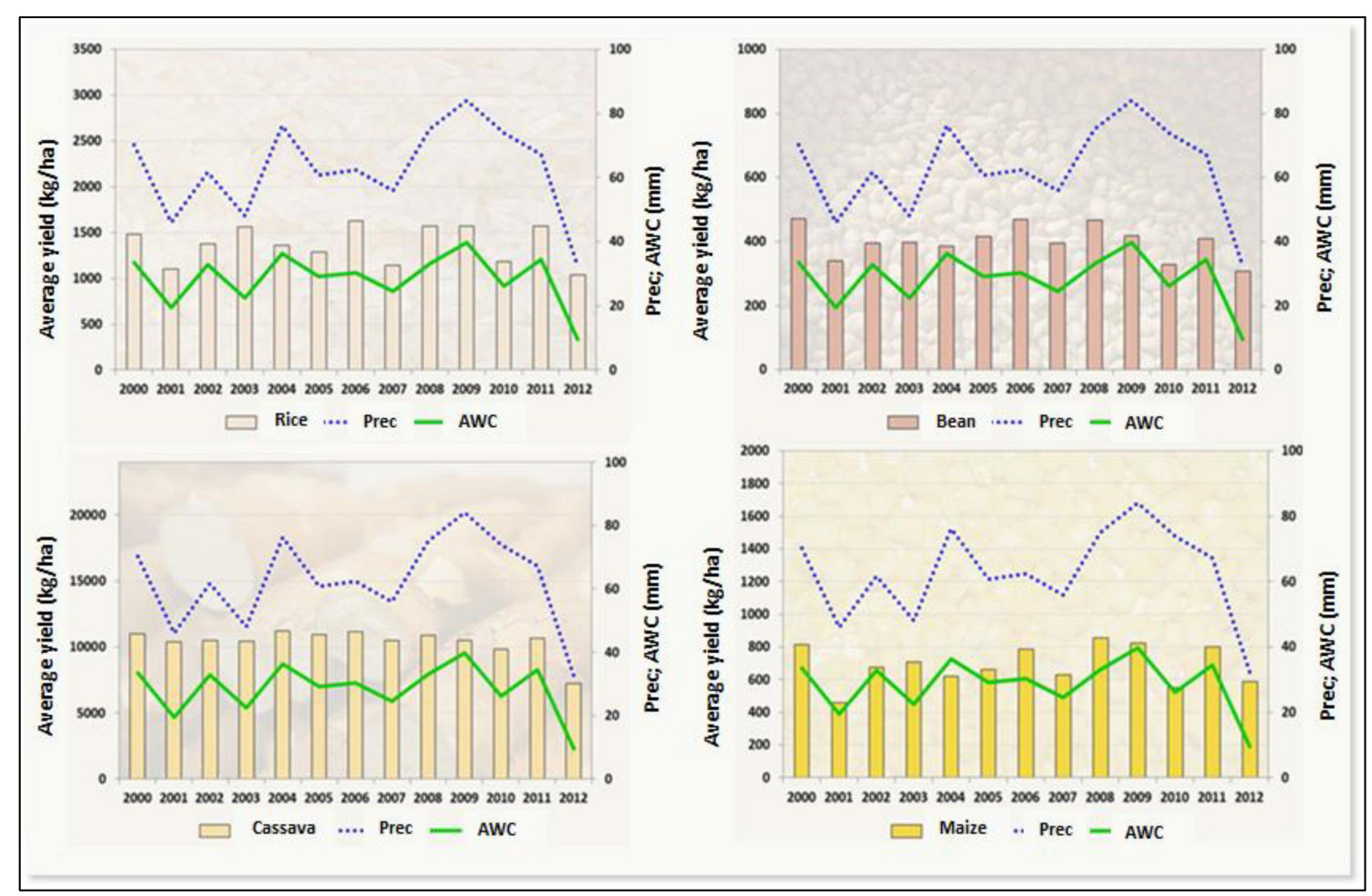

FIGURE 6 | Average annual production distribution ( $\mathrm{kg} / \mathrm{ha}$ ) of different crops (rice, beans, cassava and maize), precipitation (mm/month) and water storage in the soil $(\mathrm{mm})$ for the region of semiarid of Brazil during the period from 2000 to 2012. 


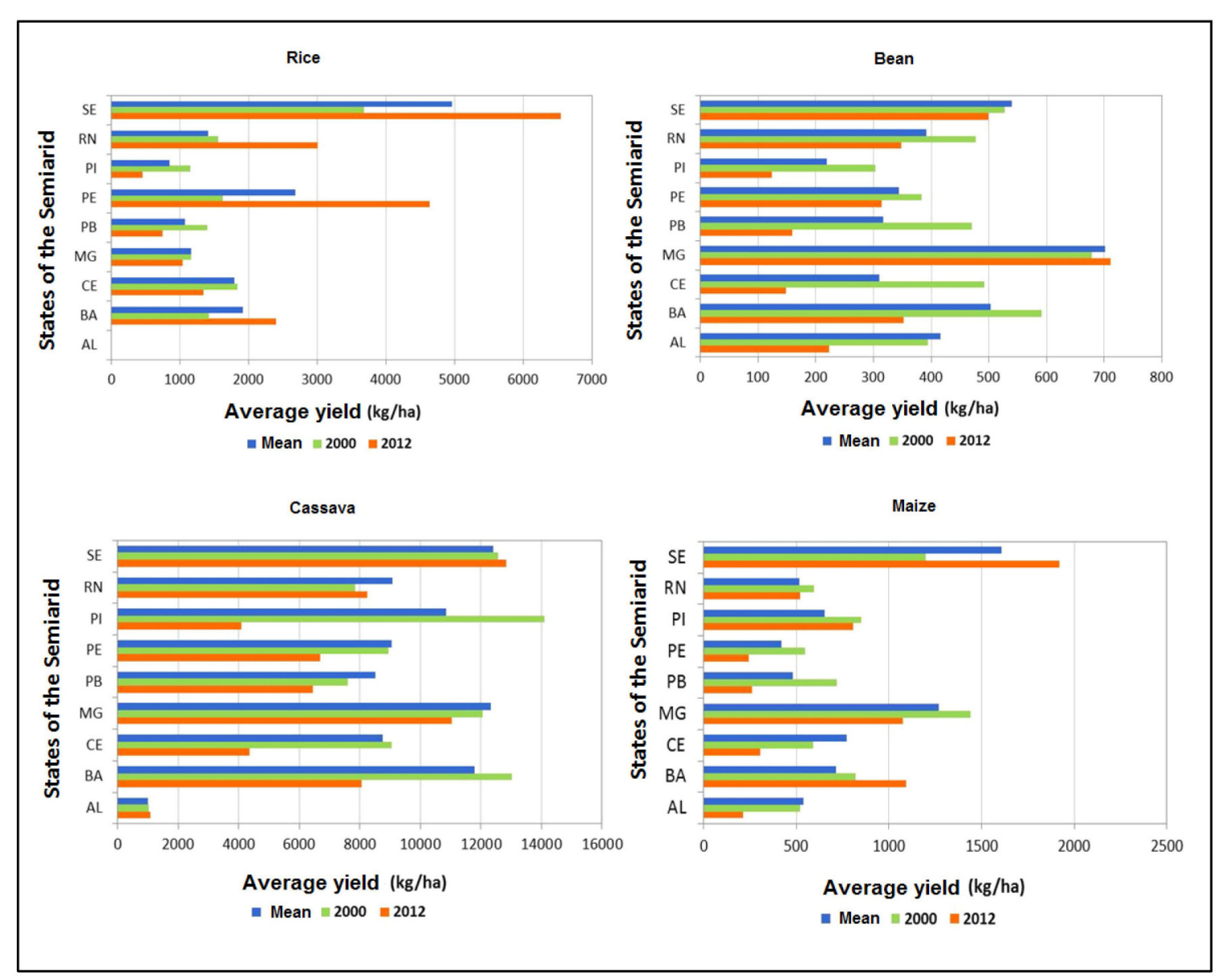

FIGURE 7 | Distribution yield (kg/ha) of different crops (rice, beans, cassava and maize) for each state of semiarid region of Brazil during the period of $2000-2012$.

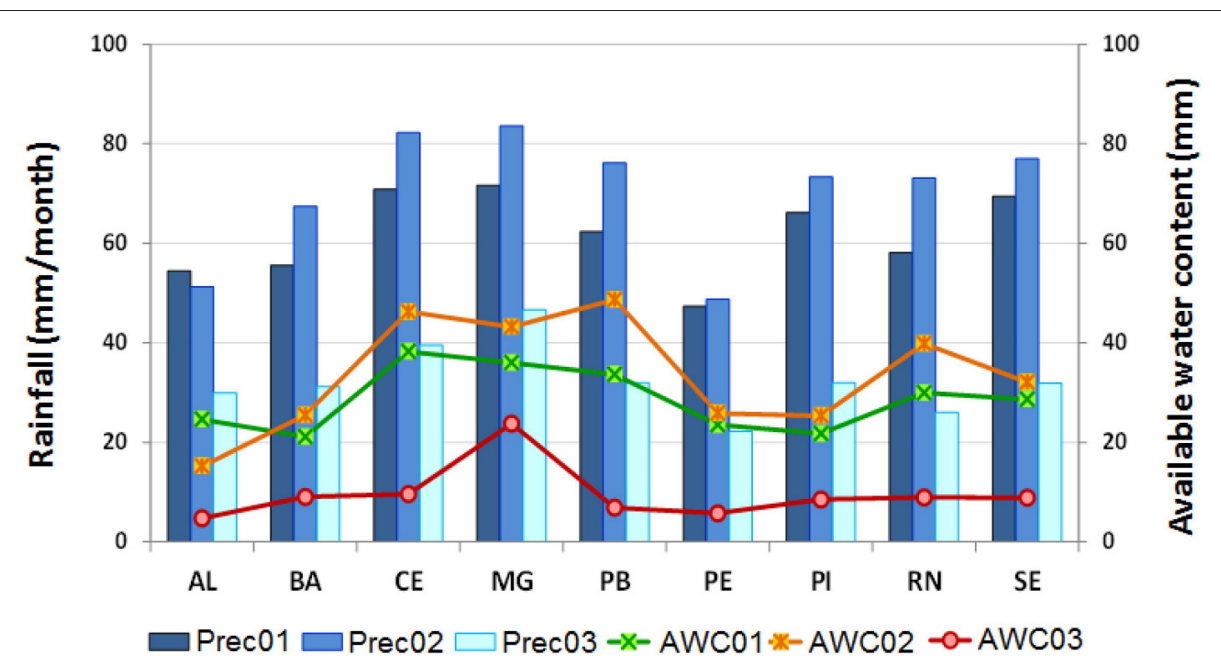

FIGURE 8 | Time series of precipitation ( $\mathrm{mm} / \mathrm{month}$ ) and available water content $(\mathrm{mm})$ for each state of the semiarid region of Brazil for three periods of analysis: climatological average of 2000-2012 (Prec01 and AWC01) and the year 2000 (Prec02 and AWC02) and 2012 (Prec03 and AWC03). 
CE, and PB States recorded a drop of up to $60 \%$ in corn yield. The CE State was the most affected by the decline in production of bean, cassava and corn, with loss of at least $50 \%$ in each of these crops in the 2012 year. Considering the cassava crop, the PI State was the most affected, with a loss of about 5,000 (kg/ha) in the harvest.

Figure 7 shows the rainfall time series ( $\mathrm{mm} / \mathrm{month})$ and water storage in the soil $(\mathrm{mm})$ for each State of the semiarid region of Brazil, considering three periods of analysis: average climatological, from 2000 to 2012, and neutral and drought years (2000 and 2012 respectively). The results show that both the precipitation and water storage in soil were above the mean value in the neutral year 2000 and both below average in the drought year 2012.

The spatio-temporal distribution of average yield (Figures 8, 9) for the four types of crops was also evaluated for the 3 study periods mentioned. The results show that during the neutral year there was an increase in the number of counties in the semiarid region with higher yield of the 4 crops; while in the drought year, the number of counties with an increase in yield dropped.

Figure 8 shows that the average yield of the rice crop, which is already reduced in the region, was also affected by drought. The average water demand for rice culture varies $450-700 \mathrm{~mm}$

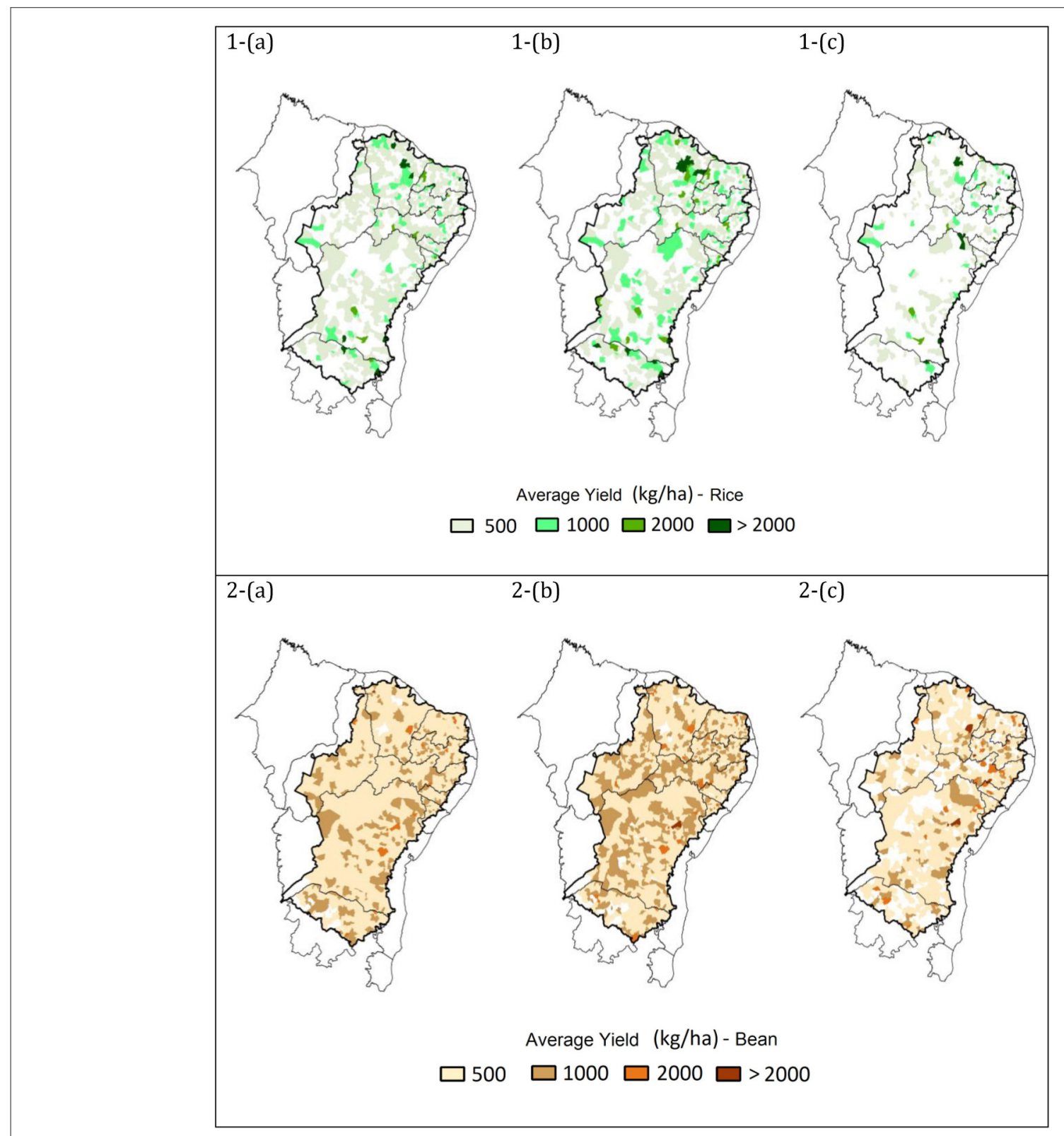

FIGURE 9 | The average yield spatia-temporal distribution (kg/ha) of rice crops (1) and beans (2) for three different periods: (a) average of 2000-2012, (b) 2000 year (c) 2012 year. The white areas there is no data. 
throughout the cycle. Another effect significant in reducing the development of plants under water deficit and drought are also related to the soil, that is, the high compression of the surface layer, which reflects the increase of bulk density and tends to reduce porosity, thereby the storage water, as highlighted by Carvalho et al. (2013).

According to Santos et al. (2001), the average cowpea bean yield, grown in rainfed conditions in the Brazilian semiarid region, is around $300 \mathrm{~kg} / \mathrm{ha}$ of grain and under irrigated conditions, can reach $1,520 \mathrm{~kg} / \mathrm{ha}$ of grain. In Figure 9 (2-c), there is a decrease in counties with average performance below $500 \mathrm{~kg} / \mathrm{ha}$.
Prolonged drought in the Northeast in 2012 also affected the production of cassava and corn (Figure 10). The negative changes in the estimates of production did not allow the production was quickly retaken, from climate average standards in the following year. In Figure 10(2-c) it is possible to evaluate the sharp decline in average corn crop yield in 2012 throughout the semiarid region. According to Marengo et al. (2013, 2016), the NEB declared a state of emergency in most districts in the region due to a drought considered the worst in 30 years, affecting more than 4 million people. According to local newspapers, from January to May 2012, the drought had already destroyed large areas of farmland, caused shortage of drinking water in hundreds

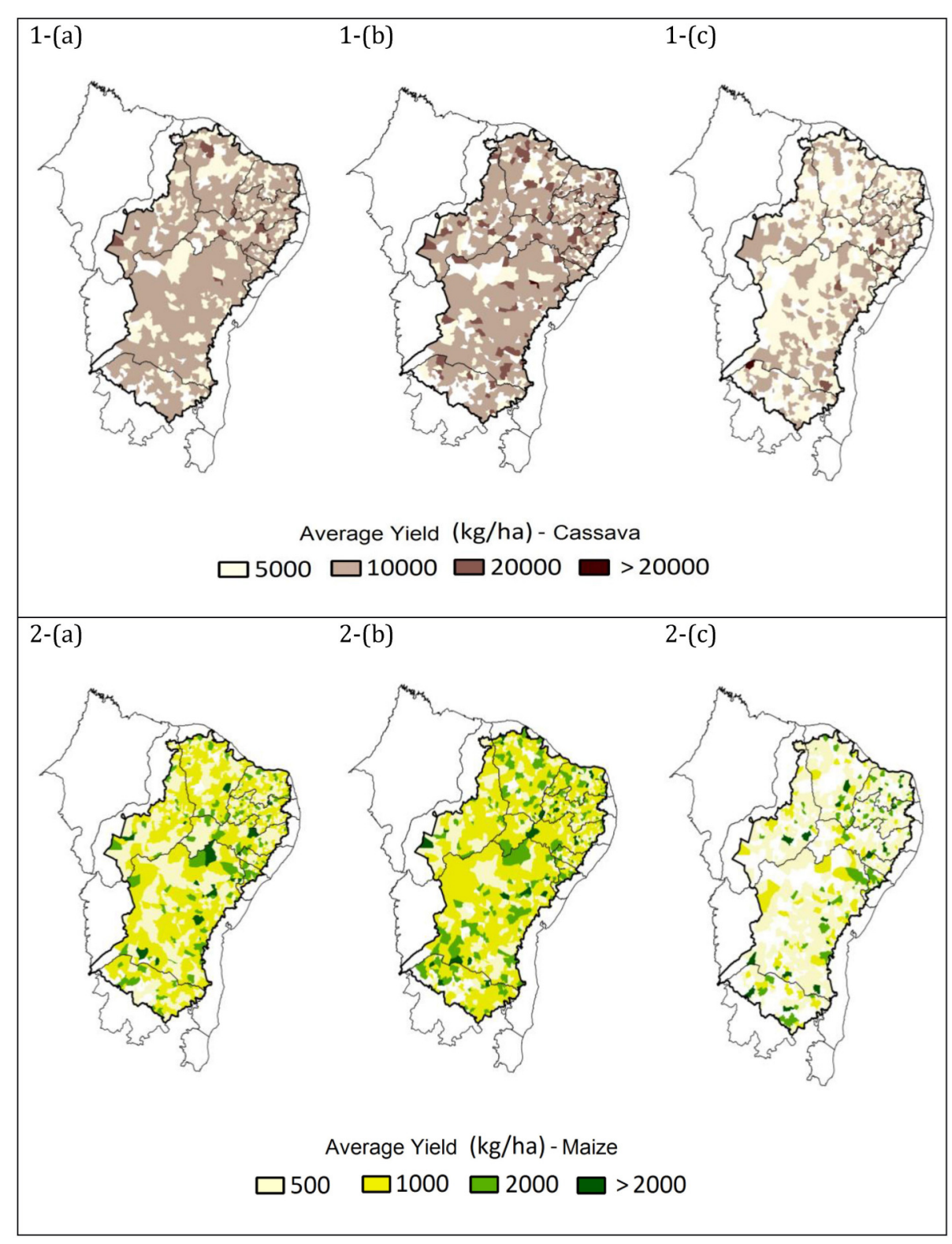

FIGURE 10 | The average yield spatia-temporal distribution (kg/ha) of cassava crops (1) and maize (2) for three different periods: (a) average of 2000-2012, (b) 2000 year (c) 2012 year. The white areas there is no data. 
of cities and towns across the region and left farmers struggling to feed and supply water to cattle.

In general, to achieve the maximum yield of the corn crop, the amount of rainfall required is $500-800 \mathrm{~mm}$ on average; however, such performance also depends on soil moisture (Doorenbos and Kassam, 1979). In the case of drought, the loss in productivity is minimal during the growing season and the maturation period; however, it is significant during the flowering and the formation periods.

To better assess the degree of association between crop yield performance and water variables (precipitation and water storage in the soil), the correlation coefficients of average crop yield with rainfall (Figure 11-1) and with soil water storage (Figure 11-2) were calculated. The results show that the performances of all four different crops were better correlated with rainfall than with soil water storage. For the soil water storage, it appears that the values of correlation coefficient are smaller. This difference may be associated with the layer used to calculate the soil water storage, ie the depth of the root system of each crop is on average $40 \mathrm{~cm}$; the water storage in soil was determined using a depth of $100 \mathrm{~cm}$. Thus, precipitation, which reaches the layer of root crops more rapidly, is correlated better with crop yields. Mohanty and Skaggs (2001) have concluded that at a particular point in time soil moisture content is influenced by precipitation, texture of the soil, slope of land surface and vegetation and land cover. For this reason, differents studies about statitistical analysis have been used to understand soil moisture variability (Jacobs et al., 2004).

In this study, statistical analysis (mean and ANOVA) were developed for each states of the Brazilian Semiarid region during 3 periods: 2000-2012, 2000, and 2012. Tables 2, 3 show values obtained to identify relationships with different crops.

Evaluating the soil moisture mean for different period (neutral, humid and dry years), we had observed that this variable is influenced by rainfall and consequently affects the crop yields for different soil and climate conditions, specified for nine states of the Brazilian Semiarid. However, this influence of the rainfall on the soil moisture is small, when analyse the spatial-temporal distribution of the correlation coefficient between the rice crops. According to Lima et al. (1999), the potential of the soil moisture in semiarid regions provides little contribution to reducing risks of low agricultural productivity. Although the rainfall and soil moisture are correlated, the impact of the crop impact is more influenced by rainfall (as shown Figure 11).

ANOVA tests (Table 3) demonstrate that $\mathrm{F}$ has a higher value (21.33) when obtained with available water content. The F test is used to determine whether two independent estimates of variance can be assumed to be estimates of the same variance (Jacobs et al., 2004). Thus, this result can be explained by difference between the correlation of all four crops with soil water, as discussed previously (Figure 11). For rainfall dataset, little differences of $\mathrm{F}$ were observed. Probably this difference between $\mathrm{F}$ values (for rainfall and soil moisture) corresponds to root penetration capacity (superficial and depth). Therefore, rainfall reaches the layer of root crops more rapidly that soil water. Finally, statistically, it is observed rainfall has an influence directly on the crops. Soil moisture has an important impact on the crop yields, but it affects indirectly.

\section{CONCLUSION}

The impact of drought on agricultural income, considering precipitation data $(\mathrm{mm} / \mathrm{month})$ and water storage in the soil $(\mathrm{mm})$ was evaluated for different crops (rice, beans, cassava and corn) in the semiarid region of Brazil, during three periods mean (2000-2012), neutral (2000), and drought (2012). The results

TABLE 3 | Analysis of variance for rainfall (month/month) and available water content (mm) during 2000-2012 period, 2000, and 2012 in Brazilian Semiarid region.

\begin{tabular}{lcrrrr}
\hline \multicolumn{7}{l}{ Analysis of variance (ANOVA) } \\
\hline \multicolumn{7}{c}{ Sum } & Mean & Variance & $\boldsymbol{F}$ & Probablity \\
\hline \multicolumn{7}{l}{ Rainfall (mm/month) } \\
$2000-2012$ & 257.43 & 28.60 & 39.84 & & \\
2000 & 301.87 & 33.54 & 131.76 & 6.28 & 4.73E-06 \\
2012 & 86.16 & 9.57 & 31.09 & & \\
\hline Available water content (mm) & & & & \\
$2000-2012$ & 563.73 & 62.64 & 69.74 & & $2.73 \mathrm{E}-08$ \\
2000 & 632.81 & 70.31 & 156.05 & 21.33 & \\
2012 & 291.52 & 32.39 & 50.85 & &
\end{tabular}

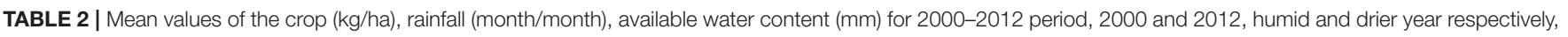
in each Brazilian Semiarid States.

\begin{tabular}{|c|c|c|c|c|c|c|c|c|c|c|}
\hline \multirow[t]{2}{*}{ State } & \multicolumn{4}{|c|}{ Crop (kg/ha) } & \multicolumn{3}{|c|}{ Rainfall (mm/month) } & \multicolumn{3}{|c|}{ Available water content (mm) } \\
\hline & Rice & Bean & Cassava & Corn & 2000-2012 & 2000 & 2012 & 2000-2012 & 2000 & 2012 \\
\hline $\mathrm{AL}$ & - & 416.01 & $9,908.01$ & 537.89 & 55.64 & 51.30 & 29.96 & 24.60 & 15.19 & 4.75 \\
\hline BA & $1,914.40$ & 503.29 & $11,794.922$ & 716.04 & 55.48 & 67.43 & 31.23 & 21.13 & 25.47 & 9.05 \\
\hline CE & 1,787.39 & 310.96 & $8,758.53$ & 770.62 & 71.77 & 82.24 & 39.61 & 38.23 & 46.25 & 9.59 \\
\hline MG & $1,167.04$ & 701.20 & $12,316.44$ & $1,268.05$ & 71.84 & 83.57 & 46.63 & 35.99 & 43.21 & 23.77 \\
\hline PB & $1,072.26$ & 317.02 & $8,508.44$ & 481.10 & 64.97 & 76.15 & 32.02 & 33.63 & 48.67 & 6.89 \\
\hline PE & 2,677.96 & 344.20 & $9,050.04$ & 420.09 & 47.89 & 48.75 & 22.19 & 23.53 & 25.85 & 5.76 \\
\hline $\mathrm{Pl}$ & 852.62 & 218.67 & $10,860.57$ & 651.71 & 67.09 & 73.31 & 31.93 & 21.75 & 25.33 & 8.54 \\
\hline $\mathrm{RN}$ & $1,405.09$ & 392.09 & $9,090.82$ & 517.65 & 60.06 & 73.05 & 26.07 & 29.96 & 39.83 & 8.94 \\
\hline SE & $4,961.28$ & 540.37 & $12,419.28$ & $1,605.28$ & 68.98 & 77.01 & 31.89 & 28.62 & 32.07 & 8.87 \\
\hline
\end{tabular}




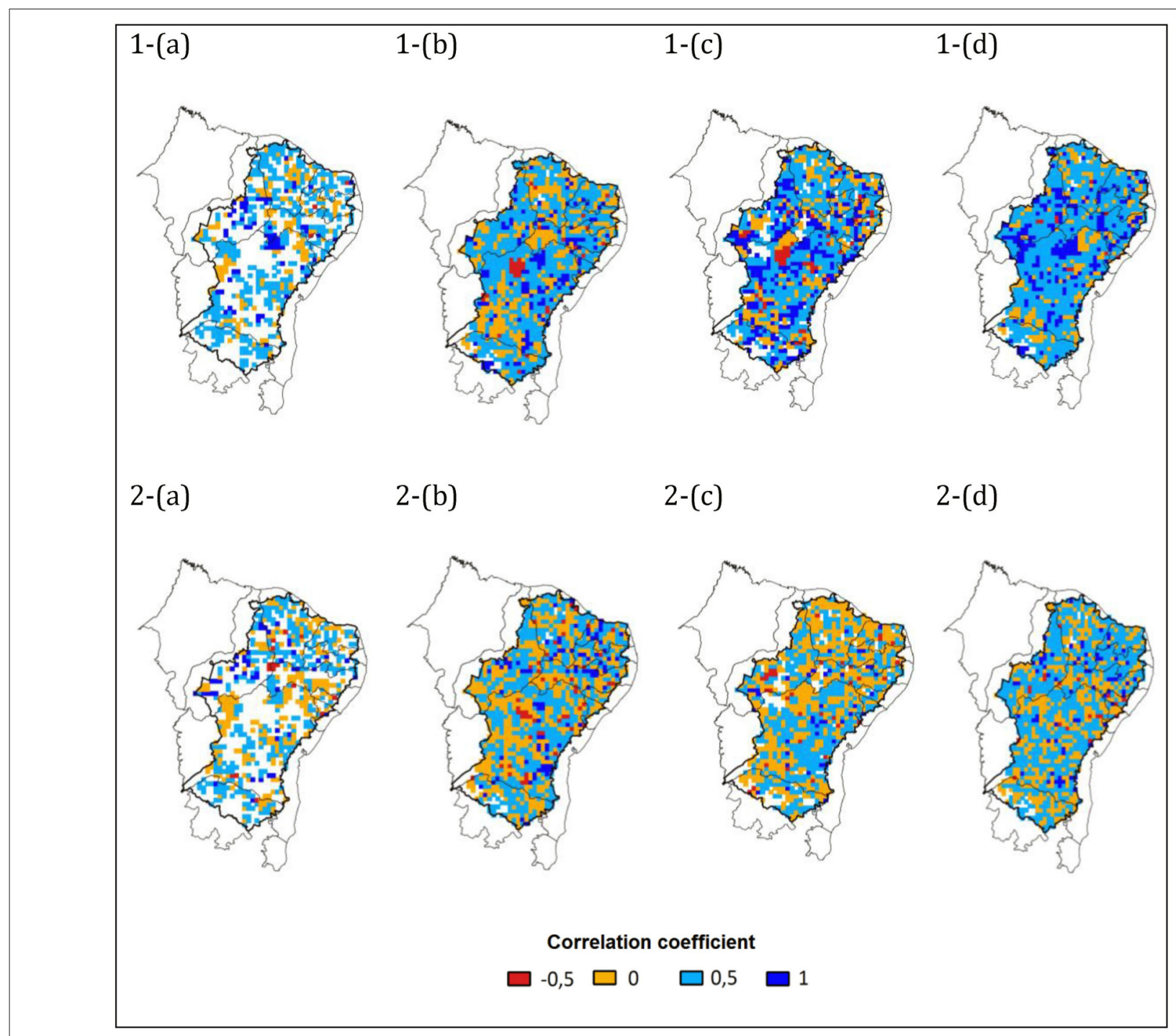

FIGURE 11 | Spatial-temporal distribution of the correlation coefficient between the rice crops (a), bean (b), cassava (c), and maize (d) and the precipitation (1) and the water storage in soil (2) during the period of 2000-2012. The white areas there is no data.

show that for the years 2003 and especially the year 2012, the study area showed lower precipitation values in relation to those observed in other years. That has led to a decrease in the water storage in soil for the Brazilian semiarid region, both in 2003 and in 2012, the last year showing the lowest levels of water in soil values. In fact, the drought of 2012 was considered the worst in 30 years in the NEB, leading to decrease in crop production in the region, mainly for the bean crops, corn, and cassava.

The results also showed that precipitation and water storage in the soil are correlated with values greater than 0.5 for almost the entire region. Thus, the precipitation and water storage in soil were above the mean value in the neutral year 2000 and both below average in the drought year 2012. On the other hand, the performances of all four different crops were better correlated with rainfall than with soil water storage. These highlights indicate that precipitation constitutes one of the limiting factors for obtaining high agricultural productivity, so that the water supply to plants is sufficient. It could be concluded that the average crop yield is directly associated with practices that increase soil moisture at the depth of the root system in order to reduce the effects caused by drought. This difference may be associated with the layer used to calculate the soil water storage, ie the depth of the root system of each crop is on average $40 \mathrm{~cm}$; the water storage in soil was determined using a depth of $100 \mathrm{~cm}$. Thus, precipitation, which reaches the layer of root crops more rapidly, correlated better with crop yields.

\section{AUTHOR CONTRIBUTIONS}

LR has investigate the relationship between water balance model with culture yields of in the semiarid region of Northeast Brazil. Moreover, the author has presented all description of this study. 
JM helped with the generation and processing of data for the Northeast region of Brazil. MZ has contributed with the structure of the study, as well as analysis and discussion results. AC has suggested the best ways of discussing the results, reviewing the balance of literature quotes, updated references and methodology presentation. LP has assisted with review of the manuscript and its translation into English. HB has contributed with revisions and discussions of the results. RA has contributed with the

\section{REFERENCES}

Ab’Saber, A. N. (1977). Os domínios morfoclimáticos na América do Sul: primeira aproximação. Geomorf. 53, 1-23.

Aina, O. O., Dixon, A. G. O., and Akinrinde, E. A. (2007). Effect of soil moisture stress on growth and yield of Cassava in Nigeria. Pak. J. Biol. Sci. 10, 3085-3090. doi: 10.3923/pjbs.2007.3085.3090

Allen, R. G., Pereira, A. L. S., Raes, D., and Smith, M. (1998). Crop Evapotranspiration: Guidelines for Computing for Computing Crop Water Requirements, Vol. 56. Rome: FAO Irrigation and Drainage Paper, 300.

Antonino, A. C. D., Sampaio, E. V. S. B., Dall'Olio, A., and Salcedo, I. H. (2000). Balanço hídrico em solo com cultivos de subsistência no semi-árido do Nordeste do Brasil. Revista Brasileira de Engenharia Agrícola Amb. 1, 29-34. doi: 10.1590/S1415-43662000000100006

Asare, D. K., Frimpong, J. O., Ayeh, E. O., and Amoatey, H. M. (2011). Water use efficiencies of maize cultivars grown under rain-fed conditions. Agric. Sci. 2, 125-130. doi: 10.4236/as.2011.22018

Badel, M. E., Sarobol, E.d., and Degewione, A. (2013). Impact of soil moisture depletion levels at different growth stages on growth, evapotranspiration and biomass yield of bread wheat grown under semi-arid condition. Agric. Sci. Eng. Technol. Res. 3, 26-34.

Barbosa, H. A., and Lakshmi Kumar, T. V. (2016). Influence of rainfall variability on the vegetation dynamics over Northeastern Brazil. J. Arid. Env. 124, 377-387. doi: 10.1016/j.jaridenv.2015.08.015

Barbosa, H. A., Lakshmi Kumar, T. V., and Silva, L. R. M. (2015). Recent trends in vegetation dynamics in the South America and their relationship to rainfall. Nat. Haz. 77, 883-899. doi: 10.1007/s11069-015-1635-8

Carrão, H., Russo, S., Supulcre-Canto, G., and Barbosa, P. (2016). An empirical standardized soil moisture index for agricultural drought assessment from remotely sensed data. Int. J. App. Earth Observ. Geol. 48, 74-84. doi: 10.1016/j.jag.2015.06.011

Carvalho, I. R., Korcelski, C., Pelissari, G., Hanus, A. D., and Rosa, G. M. (2013). Demanda hídrica das culturas de interesse agronômico. Enciclopédia Biosfera, Centro Científico Conhecer - Goiânia. Cult. Int. Agro. 17, 969-985.

Ceballos, J. C., and Moura, G. B. A. (1997). Solar radiation assessment using meteosat 4-VIS imagery. Solar Energy 60, 209-219. doi: 10.1016/S0038-092X(97)00001-7

Doorenbos, J. E., and Kassam, A. H. (1979). Yield Response to Water, Vol. 33. Roma: FAO Irrigation and Drainage Paper, 193.

Fischer, G., Velthuizen, H. V., Hizsnyik, E., and Wiberg, D. (2009). Potentially Obtainable Yields in the Semi-Arid Tropics. Global Theme on Agroec. Rep. 54, Andhra Pradesh: International Crops Research Institute for the Semi-Arid Tropics, 502-524.

Guimarães, T. T. D., Alvarenga, A. C., Dourado, L. R., Santos, G. R., and Martins, M. (2013). Diagnóstico Exploratório das Mudanças Climáticas e Estratégias Agroalimentares no Semiárido Mineiro. Cadernos de Agroec. 2, 1-5.

Hastenrath, S. (2006). Circulation and teleconnection mechanisms of Northeast Brazil droughts. Prog. Oceanogr. 70, 407-415. doi: 10.1016/j.pocean.2005.07.004

Hastenrath, S. (2012). Exploring the climate problems of Brazil's Nordeste: a review. Clim. Change 2, 243-225. doi: 10.1007/s10584-011-0227-1

He, Y., Hou, L., Wang, H., Hu, K., and McConkey, B. (2014). A modelling approach to evaluate the long-term effect of soil texture on spring wheat productivity under a rain-fed condition. Sci. Rep. 4:5736. doi: 10.1038/srep05736.

IBGE (2006). Instituto Brasileiro de Geografia e Estatística, Available online at: https://ww2.ibge.gov.br/english/ evaluation of the data, organization, analysis, and discussions of the study.

\section{ACKNOWLEDGMENTS}

This paper is a contribution of the Brazilian Research Network on Global Climate Change FINEP/ Rede CLIMA Grant 01.13.0353-00

IBGE (2013). Instituto Brasileiro de Geografia e Estatística, Available online at: https://sidra.ibge.gov.br/home/pimpfbr/brasil

INSA (2014). Instituto Nacional do Semiárido. Available online at: www.insa.gov.br IPCC (2014). Climate Change: Synthesis Report. Contribution of Working Groups I, II and III to the Fifth Assessment Report of the Intergovernmental Panel on Climate Change, eds R. K. Pachauri and L. A. Meyer. Geneva: IPCC; Core Writing Team, 151.

Jacobs, J. M., Mohanty, B. P., Hsu, E., and Miller, D. (2004). SMEX02: Field scale variability, time stability and similarity of soil moisture. Remote Sens. Environ. 92, 436-446. doi: 10.1016/j.rse.2004.02.017

Kang, Y., Khan, S., and Ma, X. (2009). Climate change impacts on crop yield, crop water productivity and food security - a review. Prog. Nat. Sci. 19, 1665-1674. doi: 10.1016/j.pnsc.2009.08.001

Leivas, J., Andrade, R., Victoria, D., Torresan, F., Bolfe, E., and Barros, T. (2012). Monitoramento da seca Ocorrida em 2012 no Nordeste Brasileiro a Partir dos dados do SPOT-Vegetation. Empresa Brasileira de Pesquisa Agropecuária. Available online at http://www.cnpm.embrapa.br/projetos/ geonetcast/download/documentos/Geonordeste2012_seca2012.pdf

Lima, M., Keymer, J. E., and Jaksic, F. M., (1999). ENSO-driven rainfall variability and delayed density dependence cause rodent outbreaks in western South America: linking demography and population dynamics. Am. Nat. 153, 476-491.

Lindoso, D. P., Rocha, J. D., Debortoli, N., Parente, I. C. I., Eiró, F., Bursztyn, M., et al. (2011). "Agricultura familiar e mudanças climáticas: avaliando a vulnerabilidade à seca no Semi-Árido Nordestino," in Mudança do clima no Brasil: aspectos econômicos, sociais e regulatórios, eds R. Seroa da Motta, J. Hargrave, G. Luedemann, and M. B. S. Gutierez (Brasília: Ipea), 277-300.

Marengo, J. A., Alves, L. M., Soares, W. R., Rodriguez, D. A., Camargo, H., Riveros, M. P., et al. (2013). Two contrasting severe seasonal extremes in tropical south america in 2012: flood in amazonia and drought in northeast Brazil. J. Clim. 26, 9137-9154. doi: 10.1175/JCLI-D-12-00642.1

Marengo, J. A., Jones, R., Alves, L. M., and Valverde, M. C. (2009). Future change of temperature and precipitation extremes in South America as derived from the PRECIS regional climate modeling system. Int. J. Clim. 29, 2241-2255. doi: $10.1002 /$ joc. 1863

Marengo, J. A., Torres, R. R., and Alves, L. M. (2016). Drought in Northeast Brazil - past, present, and future. Theor. App. Clim. 20, 1-12. doi: 10.1007/s00704-016-1840-8

Metri, A. C., Bion, F. M., Oliveira, P. S. R., and Lopes, S. M. L. (2003). Farinha de mandioca enriquecida com bioproteínas (Saccharomyces cerevisiae), em associação ao feijão e arroz, na dieta de ratos em crescimento. Rev. Nutr. 1, 73-81. doi: 10.1590/S1415-527320030001 00008

Mi, J., Liu, W., Yang, W., Yan, J., Li, J., and Sang, T. (2014). Carbon sequestration by Miscanthus energy crops plantations in a broad range semi-arid marginal land in China. Sci. Total Environ. 496, 373-380. doi: 10.1016/j.scitotenv.2014. 07.047

Mohanty, B. P., and Skaggs, T. H. (2001). Spatio-temporal evolution and time-stable characteristics of soil moisture within remote sensing footprints with varying soil, slope, and vegetation. Adv. Water Res. 24, 1051-1067. doi: 10.1016/S0309-1708(01)00034-3

Molion, L. C. B., and Bernardo, S. O. (2002). Uma revisão da dinâmica das chuvas no Nordeste Brasileiro. Rev. Brasileira Meteorol. 1, 1-10.

Moscati, M. C. L., and Gan, M. A. (2007). Rainfall variability in the rainy season of Semiarid Zone of Northeast Brazil (NEB) and its relation to wind regime. Int. J. Clim. 27, 493-512. doi: 10.1002/joc.1408 
Moura, A. D., and Shukla, J. (1981). On the dynamics of droughts in northeast brazil - observations, theory and numerical experiments with a general-circulation model. J. Atmos. Sci. 38, 2653-2675. doi: 10.1175/1520-0469(1981)038<2653:OTDODI > 2.0.CO;2

Mupangwa, W., Walker, S., and Twomlow, S., (2011). Start, end and dry spells of the growing season in semi-arid southern Zimbabwe. J. Arid. Envir. 75, 1097-1104. doi: 10.1016/j.jaridenv.2011.05.011

Obermaier, M. (2011). Velhos e Novos Dilemas nos Sertões: Mudanças Climáticas, Vulnerabilidade e Adaptação no Semiárido Brasileiro. Rio de Janeiro, Tese (Doutorado em Planejamento Energético)_COPPE, Universidade Federal do Rio de Janeiro. Rio de Janeiro.

Paredes, F. J., Barbosa, H. A., and Guevara, Y. E. (2015). Análisis espacial y temporal de las sequías en el nordeste de Brasil. Agriscientia 1, 1-14.

Pathak, P., Wani, S. P., and Sudi, R. R. (2011). Long-term effects of management systems on crop yield and soil physical properties of semiarid tropics of Vertisols. Agric. Sci. 2, 435-442. doi: 10.4236/as.2011. 24056

Rao, V. B., Lima, M. C., and Franchito, S. H. (1993). Seasonal and interannual variations of rainfall over eastern northeast Brazil. J. Clim. 6, 1754-1763.

Rao, V. B., Sá, L. D. A., Franchito, S. H., and Hada, K. (1997). Interannual variations of rainfall and corn yields in Northeast Brazil. Agric. For. Meteorol. 85, 63-74. doi: 10.1016/S0168-1923(96)02390-8

Rossato, L., Alvalá, R. C. S., and Tomasella, J. (2004). Variação espaço-temporal da umidade do solo no Brasil: análise das condições médias para o período de 1971-1990. Rev. Brasileira Meteorol. 2, 113-122.

Rossato, L., De Jeu, R., Alvalá, R. C. S., and Souza, S. S. (2011). Evaluation of soil moisture from satellite observations over South America. Int. J. Remote Sens. 23, 8013-8031. doi: 10.1080/01431161.2010.532169

Santos, C. A. F., Araujo, F. P., and Menezes, E. A. (2001). Comportamento produtivo de caupi em regimes irrigado e de sequeiro em Petrolina e Juazeiro. Pesquisa Agropecuária Brasileira 11, 2229-2234. doi: 10.1590/S0100-204X2000001100015

Santos, E., Matos, H., Alvarenga, J., and Sales, M. C. L. (2012). A seca no Nordeste no ano de 2012: relato sobre a estiagem na região e o exemplo de prática de convivência com o semiárido no distrito de Iguaçu/Canindé-CE. Rev. Geonorte 5, 819-830.

Scanlon, B. R., Keese, K. E., Flint, A. L., Flint, L. E., Gaye, C. B., Edmunds, W. M., et al. (2006). Global synthesis of groundwater recharge in semiarid and arid regions. Hydrol. Process 20, 3335-3370. doi: 10.1002/hyp.6335
Silva, V. P. R., Pereira, E. R. R., and Almeida, R. S. R. (2012). A study on annual and intra-annual variability of rainfall over Northeastern Brazil/Estudo da variabilidade anual e intra-anual da precipitação na região Nordeste do Brasil. Rev. Brasileira Meteorol. 2, 163-172. doi: 10.1590/S0102-77862012000200005

SUDENE, (2014). Superintendência do Desenvolvimento do Nordeste. Available online at: http://www.sudene.gov.br/

Small, E. E., and Kurc, S. (2002). "The influence of soil moisture on the surface energy balance in semiarid environments," in American Geophysical Union, Spring Meeting, abstract \#B32A-02. Avaliable online at: http://www.wrri.nmsu. edu/publish/techrpt/tr318/tr318.pdf

Tenório, R. S. (1989). The Meteorology of Northeast Brazil and its influence for Agriculture. Master's thesis, University of Reading, Reading.

Tomasella, J., Hodnett, M. G., and Rossato, L., (2000). Pedotransfer functions for the estimation of soil water retention in Brazilian soils. Soil Sci. Soc. Am. J. 64, 327-338. doi: 10.2136/sssaj2000.641327x

Trnka, M., Brázdil, R., MoŽný, M., Štepánek, P., Dobrovolný, P., Zahradníček, P. et al. (2015). Soil moisture trends in the Czech Republic between 1961 and 2012. Int. J. Clim. 13, 3733-3747. doi: 10.1002/joc.4242

UNDP (2013). Atlas de Desenvolvimento Humano do BrasilPrograma das Nações Unidas para o Desenvolvimento, Instituto de Pesquisa Econômica Aplicada e Fundação João Pinheiro, 2013. Available online at: www.atlasbrasil.org.br/2013/ (Accessed July 25, 2014).

van Genuchten, M. T. (1980). A closed-form equation for predicting the hydraulic conductivity of unsatured soils. Soil Sci. Soc. Am. J. 44, 892-898. doi: 10.2136/sssaj1980.03615995004400050002x

Zhang, Y., Wei, H., and Nearing, M. A. (2011). Effects of antecedent soil moisture on runoff modeling in small semiarid watersheds of southeastern Arizona. Hydrol. Earth Syst. Sci. 15, 3171-3179. doi: 10.5194/hess-15-3171-2011

Conflict of Interest Statement: The authors declare that the research was conducted in the absence of any commercial or financial relationships that could be construed as a potential conflict of interest.

Copyright (c) 2017 Rossato, Alvalá, Marengo, Zeri, Cunha, Pires and Barbosa. This is an open-access article distributed under the terms of the Creative Commons Attribution License (CC BY). The use, distribution or reproduction in other forums is permitted, provided the original author(s) or licensor are credited and that the original publication in this journal is cited, in accordance with accepted academic practice. No use, distribution or reproduction is permitted which does not comply with these terms. 